\title{
IMMUNOHISTOCHEMICAL EXPRESSION OF ANDROGEN RECEPTOR IN TRIPLE NEGATIVE BREAST CARCINOMA AT ARMED FORCES INSTITUTE OF PATHOLOGY, RAWALPINDI
}

\author{
Amna Ameer, Farhan Akhtar*, Hafeez Ud Din, Rabia Ahmed* \\ Armed Forces Institute of Pathology/National University of Medical Sciences (NUMS) Rawalpindi Pakistan, *Army Medical \\ College/National University of Medical Sciences (NUMS) Rawalpindi Pakistan
}

\begin{abstract}
Objective: To determine the frequency of immunohistochemical expression of androgen receptor in triple negative breast carcinoma.

Study Design: Cross sectional study.

Duration and Place of Study: This study included 30 cases confirmed as triple negative breast carcinoma at Armed Forces Institute of Pathology Rawalpindi, from Jan to Jul 2018.

Methodology: Anti-androgen receptor antibody was applied and assessed. Positive expression was defined as greater and equal to $10 \%$ nuclear immunostaining. SPSS-24 was used for analyzing data.

Results: Out of 30 cases of triple negative breast carcinoma (TNBC), all patients were female. Patients' ages ranged between 21-72 years with a mean age of 46.35 years and a standard deviation of \pm 13.4 . Androgen receptor expression was positive in 8 cases $(27 \%)$ of all triple negative breast carcinomas. Out of these androgen receptor (AR) triple negative breast carcinomas; all 8 cases were of histological subtype invasive ductal (mammary) carcinoma, non special type, 7 cases (23\%) were of histological grade 3 and 1 was of histological grade 2 .

Conclusion: Androgen receptor expression is observed in 8 cases $(27 \%)$ of triple negative breast carcinoma cases. Such patients can be selected as candidates for anti- androgen receptor targeted therapy.
\end{abstract}

Keywords: Androgen receptor, Breast carcinoma, Hormone receptors, Prognosis, Triple negative breast carcinoma.

This is an Open Access article distributed under the terms of the Creative Commons Attribution License (http://creativecommons.org/licenses/by/4.0), which permits unrestricted use, distribution, and reproduction in any medium, provided the original work is properly cited.

\section{INTRODUCTION}

Breast cancer is a heterogeneous group of diseases which comprises a spectrum of natural history, clinical characteristics, histopathological features and molecular subtypes, with different prognostic and therapeutic implications ${ }^{1,2}$. Breast cancer is not only the most prevalent female malignancy worldwide but is also the commonest cause of female mortality in Pakistan. One in every nine women is diagnosed with breast cancer in Pakistan ${ }^{3}$. Histopathologic factors including biomarkers, oncogenes, hormones and their receptors are valuable to predict outcome and select management strategies, as they are involved in development and genesis of breast cancer. However, there are significant differences in outcome and treatment responses and long term sur-

Correspondence: Dr Amna Ameer, Department of Histopathology, Armed Forces Institute of Pathology, Rawalpindi Pakistan

Received: 30 Jun 2020; revised received: 12 Oct 2020; accepted: 19 Oct 2020 vival among patients with the same histological subtype, grade and stage 4 .

Risk factors for breast cancer include family history, menstrual and reproductive history, fibrocystic disease, exogenous estrogens, contraceptive agents, ionizing radiation and genetics such as BRCA-1, BRCA-2, p53, retinoblastoma and human epidermal growth factor receptor-2 (HER-2) receptor status. Poor prognostic factors include younger age, higher tumor size, high grade and stage, nodal involvement, lymph vascular invasion, hormone receptor negativity and HER-2 expression.

With the advancement of molecular techniques, molecular classification of breast cancer has been developed. These molecular subtypes have a predictive and prognostic value in the management of breast cancer. Gene expression profiling is the gold standard for molecular classification. Individualized treatment programs and more 
importantly targeted therapies have become possible with the implementation of this classification $^{5}$. However due to high cost and technical difficulties involved in gene profiling, immunohistochemistry is a suitable alternative ${ }^{6}$.

There are five main intrinsic or molecular subtypes of breast cancer. These include luminal A, luminal B, HER 2 positive, Triple Negative Breast Cancers and normal breast like ${ }^{7}$. Luminal A breast cancer is hormone-receptor positive, HER-2 negative carcinoma. These are low-grade; having the best prognosis. Luminal B breast cancer is hormone-receptor positive and either HER2 positive or HER-2 negative and their prognosis is slightly worse as compared to Luminal A.

Triple Negative Breast Carcinoma (TNBC), constitute $15 \%$ of all invasive ductal carcinomas, currently there is no specific targeted therapy. There is no standard treatment regimen for TNBC. These TNBC have aggressive clinical behavior, younger age at presentation, BRCA-1 gene mutations, p53 mutations, high tumor grade, high mitotic rate and increased risk of recurrence. They have low overall survival, unresponsiveness to hormonal and anti-Her2 therapy ${ }^{8,9}$.

The treatment options of TNBC include, chemotherapeutic agents like, Taxanes and Anthracyclines as well as targeted therapies like AntiVEGF, Anti-EGFR, Anti c-KIT, PARP1 inhibitor and anti Androgen Receptors therapy ${ }^{8}$.

Androgen Receptor (AR) has emerged as a potential therapeutic target in TNBC. Recently, it has been observed that androgen and AR play an important role in the development and genesis of breast cancer. As AR belongs to nuclear steroid hormone receptor family, it has high functional, structural and topographical similarity to estrogen receptors (ER) and progesterone receptor (PR). Transcription of many androgen-regulated genes contributes to breast development and/or tumorigenesis. Existing evidence suggests an association between a higher level of AR expression and improved outcomes ${ }^{10}$.

Rationale of this study was to evaluate expression of androgen receptor in TNBC. So as to let the clinician select TNBC patients for targeted therapy against androgen receptor, this may improve overall survival.

\section{METHODOLOGY}

This cross sectional study was held at the department of Histopathology, Armed Forces Institute of Pathology, Rawalpindi from Jan to Jul 2018. Method of sampling was non-probability, consecutive sampling. Sample size was calculated using WHO calculator, however sample size was limited due to number of resection samples received during these 6 months and inadequate fixation. Thirty histopathologically proven TNBC female patients were included in this study ${ }^{11}$. Tissue samples that were included in the study were with either incisional / excisional biopsies or mastectomy specimens that had been processed and diagnosed at department of Histopathology of Armed Forces Institute of Pathology. Autolyzed specimens or specimen showing extensive necrosis were excluded from in this study. Study was approved by Institutional Review Board held at AFIP (FC-HSP 17-24/READ-IRB/18/901). Baseline clinico-pathologic data including patients' particulars, histological type and histological grade was noted.

Streptavidin-biotin method for immune staining was used. Formalin-fixed, paraffin-embedded blocks were sectioned at $3 \mu \mathrm{m}$ thickness. They were de-paraffinized in xylene. Rehydration was done with decreasing concentration of ethanol. Heat induced epitope retrieval in Tris/EDTA buffer at $\mathrm{pH} 9.0$ buffer was used for ready to use primary antibodies. Anti-Androgen Receptor (EP120) was used. An expression of $\geq 10 \%$ was defined as AR-positive expression while less than $10 \%$ AR expression was interpreted as loss of AR expression ${ }^{12}$.

Data was analyzed using Statistical Package for the Social Sciences (SPSS) version 24. Frequency and percentage was calculated for catgorical variables such as gender, histological type, histological grade and androgen receptor expression. Continuous variables were expressed as mean and standard deviation such as age. 
Percentage of categorical variables was compared using Pearson's chi-square test. The $p$-value $\leq 0.05$ was considered to be statistically significant.

\section{RESULTS}

AR expression was positive in 8/30 (26.7\%) patients, with cut off staining $\geq 10 \%$ of cells. Ages of patients ranged between 21 to 72 years with a mean age of 46.35 years and a standard deviation of \pm 13.4 (fig-1). All the cases were diagnosed as invasive ductal carcinoma (IDC) of no special type (30/30). Grade 3 disease was seen in 14/30 $(46.6 \%)$ of the cases. Whereas, $14 / 30(46.6 \%)$ cases had grade 2 and 1/30 (3.3\%) case had grade 1 disease. Of the 8 cases of positive androgen expression, 7 cases had histological grade 3 disease and 1 case had histological grade 2 . No androgen expression was seen in cases having histological grade 1 ( $p$-value $=0.025)($ fig- 2$)$.

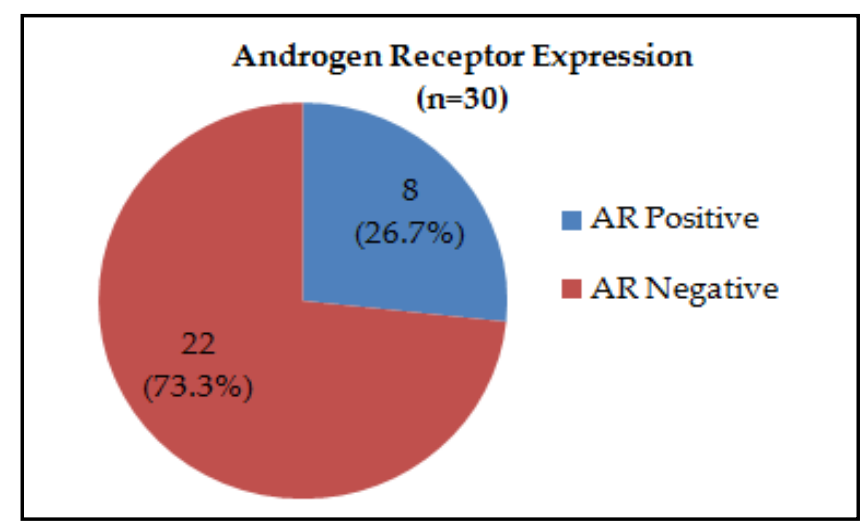

Figure-1: Percentage of Androgen expression.

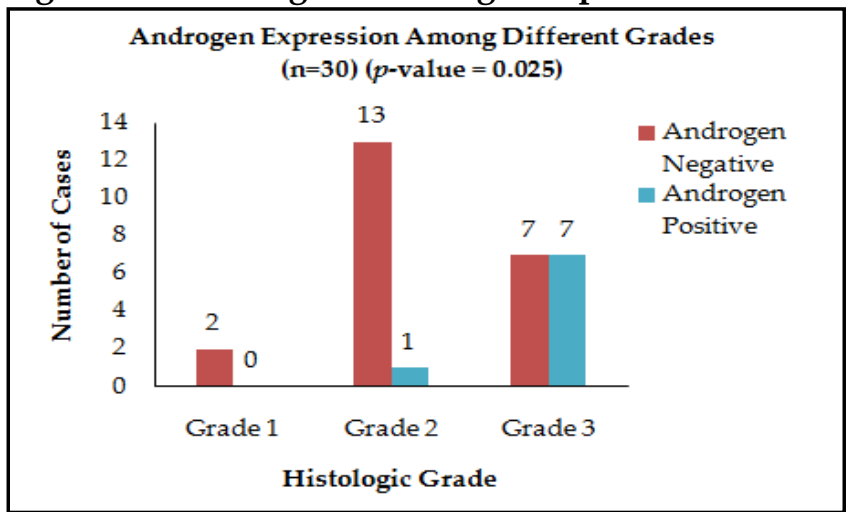

Figure 2: Androgen expression among different grades.

Lack of Androgen receptor was more in younger patients (<30 years) $8 / 9(88.8 \%)$ patients. Among 9 patients with lymph node metastasis, 5 patients showed positive AR expression ( $p$-value $=0.019$ ). Of the 27 cases that did not show presence of DCIS, 7 had positive androgen expression ( $p$-value $=0.783)$. In 23 cases lacking presence of lymphovascular invasion 4 cases showed androgen expression ( $p$-value=0.96) (table-I \& II).

Table-I: Correlation between Androgen expression and tumor stage.

\begin{tabular}{l|c|c|c|c}
\hline \multirow{2}{*}{ Stage } & \multicolumn{2}{|c|}{ Androgen } & \multirow{2}{*}{$\mathbf{n}(\%)$} & $\begin{array}{c}p- \\
\text { value }\end{array}$ \\
\cline { 2 - 3 } & Negative & Positive & & \multirow{2}{*}{0.223} \\
\hline Stage 1 & 2 & - & $16 \%$ & \\
\hline Stage 2 & 2 & 3 & $41 \%$ & \\
\hline Stage 3 & 4 & 1 & $41 \%$ & \\
\hline
\end{tabular}

Table-II: Correlation between lymph node metastasis and androgen expression.

\begin{tabular}{|c|c|c|c|c|}
\hline \multirow{2}{*}{ Stage } & \multicolumn{2}{|c|}{ Androgen } & \multirow{2}{*}{ n $(\%)$} & \multirow{2}{*}{$\begin{array}{c}p- \\
\text { value }\end{array}$} \\
\hline & Negative & Positive & & \\
\hline Not Seen & 18 & 3 & $70 \%$ & \multirow{2}{*}{0.019} \\
\hline Seen & 4 & 5 & $30 \%$ & \\
\hline
\end{tabular}

\section{DISCUSSION}

The study aimed to assess Androgen receptor expression prevalence in 30 female patients. These patients were diagnosed as triple negative breast carcinoma at Armed Forces Institute of Pathology, Rawalpindi. It was observed that AR was expressed positively in 8/30 (26.7\%) patients. This positive expression of AR was significantly correlated with tumor grade and lymph node metastasis with $p$-value $<0.05$. However, no significant correlation was established between AR expression and age, presence of DCIS or lymphovascular invasion.

In comparison to other studies, a large systematic review was done that included 7693 breast cancer patients in 19 studies, it was observed that out of all estrogen positive cases $74.8 \%$ showed Androgen expression. This percentage was 31.8\% in estrogen negative tumors ${ }^{13}$. Androgen expression was seen in 74 out of 287 patients with TNBC $(25.8 \%)$ according to He et al13. Similarly, $23 \%$ of a total 94 patients with TNBC showed AR expression in a study by Mc Ghan et al14. Ten percent of patients having TNBC were reported to have androgen expression by Neimeier et al16. Other similar studies observed that $10-43 \%$ of TNBCs reported expression of $\mathrm{AR}^{17,18}$. In a meta- 
analysis including 13 studies of 2826 patients, $24.4 \%$ patients shows positive AR expression ${ }^{19}$. This study results are in concordance with these studies.

TNBC is a heterogeneous disease and numerous studies have shown further classification of TNBC based on its genetic profile, AR positive TNBC is one such subtype ${ }^{10,15}$. It also shows that preserved androgenic signaling could be a potential therapeutic molecular target similar to estrogen receptor positive carcinoma of breast ${ }^{18}$. In addition to this, $70-90 \%$ of breast carcinoma cases
TNBC prognosis is poor when compared to patients of other subtypes and this difference in mortality rates and recurrences can be attributed partly to their different genetic subtype in this entity of breast cancer. Adverse effects in proliferation of breast cancer cells as a result of signals generated by AR expression has also been observed in few cancer cell lines given 5-alpha-dihydrotestosterone treatment. This mechanism could lead to relapse of breast cancer ${ }^{24}$. Exact characteristics of AR-positive TNBCs can only be determined through additional studies (table-III).

Table-III: Comparison with other studies.

\begin{tabular}{l|c|c|c|c}
\hline & $\begin{array}{c}\text { Present Study } \\
\text { (AFIP) } \mathbf{( n = 3 0 )}\end{array}$ & $\begin{array}{c}\text { Farag } \text { et al } \\
\text { (Egypt) }(\mathbf{n}=\mathbf{9 0})\end{array}$ & $\begin{array}{c}\text { Asano } \text { et al. } \\
\text { (Japan) }(\mathbf{n}=\mathbf{1 9 0})\end{array}$ & $\begin{array}{c}\text { Zakaria } \text { et al. } \\
\text { (Egypt) (n=77) }\end{array}$ \\
\hline Age (years) & $\begin{array}{c}21-72 \\
\text { Mean }=46.35\end{array}$ & $\begin{array}{c}27-77 \\
\text { Mean }=46.5\end{array}$ & Mean $=55$ & $\begin{array}{c}19-63 \\
\text { Mean }=35.6\end{array}$ \\
\hline Histologic type (IDC) & $100 \%$ & $82 \%$ & $84 \%$ & $92 \%$ \\
\hline Tumour grade III & $37 \%$ & $40 \%$ & $56.3 \%$ & $32 \%$ \\
\hline $\begin{array}{l}\text { Lympovascular Invasion, } \\
\text { Present }\end{array}$ & $21.1 \%$ & - & $28.9 \%$ & - \\
\hline Ductal carcinoma in situ, Present & $22 / 30$ & - & - & - \\
\hline Androgen receptor expression & $8 / 30(27 \%)$ & $27 / 90(30 \%)$ & $56 / 190(29.5 \%)$ & $21 / 77(27 \%)$ \\
\hline
\end{tabular}

give AR expression which is comparable to the rate of estrogen expression. Previous studies suggest that androgens are involved in the reduction of breast cancer evolution however, it is still uncertain what exact mechanisms and clinical significance of androgen receptor in breast cancer is involved in this process $20-22$. Role of Androgen signaling in breast cancer development remains controversial, however, androgen is involved in influencing breast cancer risk throughout various methods: either though binding of AR in turn stimulating production of malignant cells or through ER binding leading to competitive inhibition of 17 bestradiol stimulatory effect on tumor cells, or through conversion to estradiol ${ }^{23}$. AR negativity was significantly associated with distant metastasis, recurrences and histologic grade according to a study by Lou et al17. While in a study conducted by Wang et al, AR positive cases had lower tumor grade $(p<0.001)$, but had lymph node metastases $(p<0.0 .1)^{19}$.

\section{CONCLUSION}

Androgen receptor expression was observed in $8 / 30(26.7 \%)$ patients of triple negative breast carcinoma. Such patients can be selected as candidates for outcome of disease as well as a predictive marker of novel targeted therapy in this distinct subtype of breast cancer. More such studies with greater number of patients and longer follow up is required to reduce controversial results.

\section{CONFLICT OF INTEREST}

This study has no conflict of interest to be declared by any author.

\section{REFERENCES}

1. Formenti SC, Arslan AA, Love SM. Global breast cancer: the lessons to bring home. Int J Breast Cancer 2012; 2012: 249501.

2. Onitilo AA, Engel JM, Greenlee RT. Breast cancer subtypes based on ER/PR and Her2 expression: comparison of clinicopathologic features and survival. Clin Med Res 2009; 7(1-2): 4-13.

3. Sohail S, Alam SN. Breast cancer in Pakistan-awareness and early detection. J Coll Physicians Surg Pak 2007; 17(12): 711-12.

4. Leong AS, Zhuang Z. The changing role of pathology in breast cancer diagnosis and treatment. Pathobiol 2011; 78(2): 99-114. 
5. Coleman WB, Anders CK. Discerning clinical responses in breast Cancer based on molecular signatures. Am J Pathol 2017; 187(10): 2199-207.

6. Sheffield BS. Immunohistochemistry as a practical tool in molecular pathology. Arch Pathol Lab Med 2016; 140(8): 766-69.

7. Eliyatkın N, Yalçın E, Zengel B, Aktaş S, Vardar E. Molecular classification of breast carcinoma: from traditional, old-fashioned way to a new age, and a new way. J Breast Health 2015; 11(2): 59-63.

8. Oualla K, El-Zawahry HM, Arun B, Reuben JM, Woodward WA, Gamal El-Din H, et al. Novel therapeutic strategies in the treatment of triple-negative breast cancer. Ther Adv Med Oncol 2017; 9(7): 493-511.

9. Kaplan HG, Malmgren JA. Impact of triple negative phenotype on breast cancer prognosis. Breast J 2008; 14(5): 456-63.

10. Gucalp A, Traina TA. Triple-negative breast cancer: role of the androgen receptor. Cancer J 2010; 16(1): 62-65.

11. Idrees R, Fatima S, Abdul-Ghafar J, Raheem A, Ahmad Z. Cancer prevalence in Pakistan: meta-analysis of various published studies to determine variation in cancer figures resulting from marked population heterogeneity in different parts of the country. World J Surg Oncol 2018; 16(1): 129.

12. Farag K, Elfarargy OM, El Shorbagy S, Salem RA, Balata SA, Abdel-latif RM, et al. Prevalence of androgen receptors expression in triple negative breast cancer patients and its correlation with clinicopathological criteria: our institutes experience. Menopause. J Clin Oncol 2017; 4(10): 11-15.

13. Vera-Badillo FE, Templeton AJ, de Gouveia P, Diaz-Padilla I, Bedard PL, Al-Mubarak M, et al. Androgen receptor expression and outcomes in early breast cancer: a systematic review and meta-analysis. J Natl Cancer Inst 2014; 106(1): djt319.

14. He J, Peng R, Yuan Z, Wang S, Peng J, Lin G, et al. Prognostic value of androgen receptor expression in operable triple-negative breast cancer: a retrospective analysis based on a tissue microarray. Med Oncol 2012; 29(2): 406-10.
15. McGhan LJ, McCullough AE, Protheroe CA, Dueck AC, Lee JJ, Nunez-Nateras R, Castle EP, Gray RJ, et al. Androgen receptorpositive triple negative breast cancer: a unique breast cancer subtype. Ann Surg Onco 2014; 21(2): 361-77.

16. Niemeier LA, Dabbs DJ, Beriwal S, Striebel JM, Bhargava R. Androgen receptor in breast cancer: expression in estrogen receptor-positive tumors and in estrogen receptor-negative tumors with apocrine differentiation. Mod Pathol 2010; 23(2): 205-12.

17. Luo X, Shi Y, Li Z, Jiang W. Expression and clinical significance of androgen receptor in triple negative breast cancer. Chin J Cancer 2010; 29(6): 585-90.

18. Lehmann BD, Bauer JA, Chen $X$, Sanders ME, Chakravarthy AB, Shyr Y, Pietenpol JA. Identification of human triple-negative breast cancer subtypes and preclinical models for selection of targeted therapies. J Clin Invest 2011; 121(7): 2750-67.

19. Wang C, Pan B, Zhu H, Zhou Y, Mao F, Lin Y, et al. Prognostic value of androgen receptor in triple negative breast cancer: $\mathrm{A}$ meta-analysis. Oncotarget 2016; 7(29): 46482.

20. Ando S, De Amicis F, Rago V, Carpino A, Maggiolini M, Panno $\mathrm{ML}$, et al. Breast cancer: from estrogen to androgen receptor. Mol Cell Endocrinol 2002; 193(1-2): 121-28.

21. De Launoit $Y$, Veilleux R, Dufour M, Simard J, Labrie F. Characteristics of the biphasic action of androgens and of the potent antiproliferative effects of the new pure antiestrogen EM-139 on cell cycle kinetic parameters in LNCaP human prostatic cancer cells. Cancer Res 1991; 51(19): 5165-70.

22. Poulin R, Baker D, Labrie F. Androgens inhibit basal and estrogen-induced cell proliferation in the ZR-75-1 human breast cancer cell line. Breast Cancer Res Treat 1988; 12(2): 213-25.

23. Yu Q, Niu Y, Liu N, Zhang JZ, Liu TJ, Zhang RJ, et al. Expression of androgen receptor in breast cancer and its significance as a prognostic factor. Ann Oncol 2011; 22(6): 1288-94.

24. Greeve MA, Allan RK, Harvey JM, Bentel JM. Inhibition of MCF7 breast cancer cell proliferation by 5alpha-dihydrotestosterone; a role for p21 (Cip1/Waf1). J Mol Endocrino 2004; 32(3): 793-810. 